\title{
PEMBINAAN KARAKTER MAHASISWA BERBASIS LIVING VALUES EDUCATION
}

\author{
Hayati Nufus \\ Prodi PAI FITK IAIN Ambon \\ Email : nufushayati119@gmail.com
}

\begin{abstract}
This study supports providing solutions to foster student character in the Ambon IAIN environment based on the Living Values Education program. This research is a qualitative descriptive type with instruments of interview (interview) and FGD (focus group discussions), the LVE material used is the values of peace, appreciation, love, unity and divinity (religious). The subjects of this study were the third semester FITK IAIN Ambon students consisting of majors namely Islamic Education and Biology Education which were filled with 23 people and 2 lecturers from two majors. This study uses descriptive narrative analysis. The results of the study provide an overview of Life Values Education must be carried out and developed in everyday life. Whether it is a character building course that is integrated with all existing courses before all teaching staff (lecturers) become role models for students. As well as students realize that the value must be grown in themselves as self control to encourage each learning.
\end{abstract}

Keywords: Character Building, Life Value Education

\begin{abstract}
ABSTRAK : Penelitian ini bertujuan untuk memberikan rekomendasi solusi pembinaan karakter mahasiswa di lingkungan IAIN Ambon berdasarka program Living Values Education. Penelitian ini berjenis deskriptif kualitatif dengan Instrument penelitian wawancara (interview) dan FGD (focuss group discussion), Adapun materi LVE yang digunakan adalah nilai-nilai kedamaian, penghargaan, cinta, persatuan dan ketuhanan (religious). Subyek penelitian ini adalah mahasiswa semester III FITK IAIN Ambon yang terdiri dari jurusan yaitu Pendidikan Agama Islam dan Pendidikan Biologi berjumlah 23 orang dan 2 orang dosen dari dua jurusan. Penelitian ini menggunakan analisis deskriptif naratif. Hasil penelitian memberikan gambaran bahwa Living Values Education harus dilakukan dan terus dikembangkan dalam kehidupan sehari-hari. Baik itu sebagai mata kuliah pembinaan karakter tersendiri maupun terintegrasi dengan semua mata kuliah yang ada terlebih jika semua staf pengajar (dosen) menjadi tauladan bagi mahasiswa. Serta mahasiswa menyadari bahwa nilai itu harus ditumbuhkembangkan dalam dirinya sebagai self control untuk menjalani setiap pembelajaran.
\end{abstract}

Kata Kunci : Pembinaan Karakter, Living Values Education

\section{PENDAHULUAN}

Socrates mengatakan bahwa pendidikan merupakan proses pengembangan manusia ke ara $\mathrm{h}$ kearifan (wisdom), pengetahuan (knowledge), dan etika (conduct). Oleh karenanya membangun aspek kognisi, afeksi dan psikomotor secara seimbang dan berkesinambungan adalah nilai pendidikan yang paling tinggi. (Zeim alMubarak, 2009: 3). 
Ada dua peristiwa yang membuat pendidikan itu utama dan pertama, yaitu pertama, ketika pada 4 Oktober 1957, Uni Sovyet meluncurkan pesawat luar angkasanya spotnic yang pertama. Amerika Serikat saat itu meradang, bagaimana tidak, Amerika adalah Negara besar dengan kemampuan teknologi paling maju dikalahkan oleh Uni Sovyet. Segera Presiden Amerika membentuk tim khusus untuk merespon kejadian itu, tetapi bukan tim untuk menandingi kecanggihan Sovyet. Tim khusus ini bertugas meninjau kembali kurikulum pendidikan AS mulai dari jenjang pendidikan dasar sampai tingkat perguruan tinggi. Suatu tindakan politik di luar perkiraan banyak orang. Akhirnya dengan bekerja keras tim khusus pun berhasil dan mengeluarkan pernyataan bahwa kurikulum pendidikan AS di semua jenjang sudah tidak layak lagi dan harus direvisi.

Berdasarkan temuan tim khusus itu maka Amerika pun melakukan pembaharuan pendidikan dalam segala segi dan dimensinya. Mulai dari kurikulum, mata pelajaran, tenaga pengajar, sarana pendidikan sampai kepada system evaluasi pendidikan. Usaha AS membuahkan hasil dengan cepat dan sangat luar biasa. Akhirnya pada tanggal 14 juli 1969 AS berhasil meletakkan manusia pertama di bulan. Hanya dalam waktu 12 tahun, mereka berhasil mengungguli teknologi uni Sovyet. (Zeim alMubarak, 2009: 3).

Kedua, Jepang kalah pada perang dunia II dengan dibomnya kota Nagasaki dan Hiroshima pada tanggal 6 dan 9 Agustus 1945. Jepang lumpuh dalam segala segi kehidupan. Bahkan kaisar Jepang menyatakan bahwa mereka sudah tidak memiliki apapun kecuali tanah air saja. Saat itu Kaisar langsung memanggil pucuk pimpinan dan bertanya : Berapa orang guru yang masih hidup? Pertanyaan sederhana tapi mengandung makna bahwa pendidikan adalah awal dari segalanya.

Jepang bangkit dengan memperbaharui system pendidikan mereka di semua jenjang. Dalam waktu yang relatif singkat Jepang berhasil membangun Negara mereka menjadi Negara yang kuat dalam bidang ekonomi dan pendidikan. Bahkan merupakan Negara ekonomi terkuat yang menjadi ancaman AS. 
Dua peristiwa di atas memperlihatkan gambaran nyata dari urgensi pendidikan yang telah dipahami dan diaplikasikan dengan baik oleh AS dan Jepang. Langkah yang mereka ambil telah membuktikan kepada dunia bahwa kemajuan pendidikan berarti kemajuan sebuah bangsa. Dan bangsa manapun yang mengabaikan pendidikan maka tunggu saja kehancurannya. Hal ini berarti bahwa segala macam krisis yang terjadi akan dapat teratasi dengan pendidikan yang baik dan sistematis.

Pendidikan yang baik berarti adalah pendidikan yang bernilai, karena yang paling penting di dunia ini adalah nilai moral (akhlak) manusia. Secara garis besar nilai dibagi dalam dua kelompok yaitu nilai nurani (values of being) dan nilai-nilai memberi (values of giving). Nilai-nilai nurani adalah nilai yang ada dalam diri manusia yang kemudian berkembang menjadi perilaku serta cara kita memperlakukan orang lain, seperti nilai kejujuran, keberanian, cinta damai, keandalan diri, potensi diri,disiplin, tahu batas, kemurnian dan kesesuaian. Sedangkan nilai-nilai memberi adalah nilai yang perlu dipraktekan atau diberikan kepada orang lain yang kemudian akan diterima sebanyak yang diberikan. Nilai-nilai tersebut adalah setia, dapat dipercaya, hormat, cinta,kasih sayang, peka, tidak egois, baik hati, ramah, adil dan murah hati. (Zeim alMubarak, 2009: 7).

Nilai-nilai itu seharusnya menjadi milik bersama di dalam satu masyarakat agar menjadi perekat bagi masyarakat itu sendiri. Kalau suatu masyarakat sudah mempunyai nilai yang sama tentang yang berguna dan tidak berguna, tentang yang cantik dan tidak cantik, tentang yang baik dan buruk, maka masyarakat seperti itu sudah direkat oleh suatu norma yang sama, sehingga anggota masyarakat itu akan mempunyai rasa solidaritas yang tinggi. Sehingga jika nilai-nilai ini telah menjadi milik bersama dan telah tertanam dengan emosi yang mendalam, maka anggota masyarakat itu akan bersedia berkorban dan berjuang untuk mempertahankan nilai-nilai itu, misalnya saja mempertahankan tanah air dari penjajahan.

Nilai-nilai tersebut di atas akan sangat bermakna dan dapat dipraktekan ketika nilai-nilai itu dihidupkan melalui pendidikan nilai (values education). 
Istilah pendidikan nilai masih terasa asing di telinga masyakat Indonesia bahkan di dunia pendidikan sekalipun. Hal ini karena, pertama masyarakat belum merasakan kontribusi nilai atau moral yang diperoleh melalui rahim pendidikan nilai. Kedua, pendidikan nilai belum menjadi kajian ilmiah yang digandrungi masyarakat luas, hal ini terbukti pendidikan nilai belum dijadikan satu program studi yang menjadi pilihan civitas akademik. Ketiga, pada program-program studi pendidikan lainnya istilah pendidikan nilai tidak dikenalkan melalui pemberian mata kuliah tersendiri juga tidak diintegrasikan dalam mata kuliah-mata kuliah lainnya.

Berdasarkan hal itu maka pendidikan nilai merupakan bantuan terhadap peserta didik agar menyadari dan mengalami nilai-nilai yang sejatinya sudah ada dalam dirinya untuk ditempatkan secara integral dalam keseluruhan hidupnya. Oleh karena itu pendidikan nilai bukanlah kurikulum tersendiri yang diajarkan lewat beberapa matakuliah akan tetapi mencakup seluruh proses pendidikan, disebabkan pendidikan nilai adalah ruh pendidikan itu sendiri. Jadi dimanapun diajarkan tentang pendidikan maka nilai akan muncul dengan sendirinya. Dengan kata lain bahwa pendidikan nilai adalah nilai pendidikan.

Konsep awal Pendidikan Nilai adalah komponen yang menyentuh filosofi tujuan pendidikan yaitu memanusiakan manusia, membangun manusia paripurna dan membentuk insan kamil atau manusia seutuhnya. Persoalan yang paling mendasar untuk memanusiakan manusia seutuhnya adalah adanya pengakuan dan penghargaan akan nilai-nilai kemanusiaan. Hal ini akan timbul manakala ranah afeksi dalam diri seseorang dihidupkan. Itu berarti dalam proses pembelajaran, perkembangan perilaku anak dan pemahamannya mengenai nilai-nilai moral seperti keadilan, kejujuran, rasa tanggung jawab serta kepedulian terhadap orang lain merupakan elemen yang tidak dapat dipisahkan dari unsur pendidikan.

Kesadaran seseorang akan nilai humanitas pertama kali muncul bukan melalui teori atau konsep, melainkan melalui pengalaman konkrit yang langsung dirasakan baik di rumah, sekolah maupun masyarakat 
lingkungannya. Pengalaman itu meliputi sikap dan prilaku orang tua dan guru yang baik, penilaian adil yang mereka terapkan, pergaulan yang menyenangkan yang mereka dapatkan serta lingkungan yang sehat dengan penekanan sikap positif seperti penghargaan terhadap keunikan dan perbedaan. Pengalaman-pengalaman seperti inilah yang berperan membentuk emosi seseorang berkembang dengan baik.

Jika pengalaman-pengalaman hidup yang baik itu selalu didapatkan, maka akan timbul kesadaran moral yang mengarahkan seseorang mampu membuat pertimbangan secara matang atas perilakunya dalam kehidupan sehari-hari baik di rumah, sekolah ataupun di masyarakat. Oleh karena itu dalam proses pembelajaran hendaknya selalu memperhatikan keseimbangan antara dimensi kognitif dan afektif. Maksudnya adalah untuk membentuk manusia seutuhnya tidak cukup hanya dengan mengembangkan kecerdasan pikir atau intelegensi seseorang melalui segudang ilmu pengetahuan, melainkan juga harus dibarengi dengan pengembangan perilaku dan kesadaran moral. Karena dengan kombinasi atau perpaduan seperti itulah seseorang akan mampu menghargai nilai-nilai humanitas di dalam dirinya dan orang lain.

Hal ini sangat dibutuhkan berdasarkan beberapa peristiwa yang terjadi dewasa ini seperti masih banyak dan semakin banyak anak di dunia yang menjadi korban kekerasan, masalah-masalah sosial yang semakin meningkat dan kurangnya sikap saling menghargai antarmanusia dan terhadap lingkungan sekitar. Para orang tua dan pengajar di banyak negara meminta bantuan untuk mengubah kondisi yang memprihatinkan ini. Dan akhirnya banyak dari mereka percaya bahwa bagian dari solusinya adalah dengan menghidupkan pendidikan nilai. Maka kemudian lahirlah istilah Living Values: An Educational Program yang dibuat sebagai jawaban dari kebutuhan akan nilai-nilai kehidupan ini. 


\section{METODE}

Penelitian ini berjenis deskriptif kualitatif dengan Instrument penelitian wawancara (interview) dan FGD (focuss group discussion), Adapun materi LVE yang digunakan adalah nilai-nilai kedamaian, penghargaan, cinta, persatuan dan ketuhanan (religious). Subyek penelitian ini adalah mahasiswa semester III FITK IAIN Ambon yang terdiri dari jurusan yaitu Pendidikan Agama Islam dan Pendidikan Biologi berjumlah 23 orang dan 2 orang dosen dari dua jurusan. Penelitian ini menggunakan analisis deskriptif naratif yang hanya memaparkan hasil temuan yang terkait dengan penelitian.

\section{HASIL}

\section{Pembinaan Karakter}

Karakter menurut bahasa adalah sifat bawaan, suara hati, pancaran jiwa, jati diri kepribadian, budi pekerti, perilaku, personalitas, sifat tabiat, temperamen atau watak. (suyanto, 2010 : 39). Sedangkan menurut istilah adalah cara berpikir dan berperilaku yang menjadi ciri khas tiap individu untuk hidup dan bekerja sama baik dalam lingkup keluarga, masyarakat, bangsa maupun negara. (Kemendiknas, 2010 : 12). Karakter juga dimaknai sebagai integritas dari pengetahuan tentang kebaikan, mau berbuat baik, dan berperilaku baik,yang dibuktikan dalam kehidupan nyata. Oleh karena itu seseorang dapat diamati dari tiga aspek yaitu mengetahui kebaikan, menyukai dan melakukian kebaikan. (Taufiqurrahman, 2018: 6).

Karakter baik perlu ada pembinaan, pembinaan yang dimaksudkan adalah pembiasaan perilaku baik yang terus menerus dilakukan. Dalam hal ini adalah pembinaan karakter yang akan diingrasikan dengan pendidikan nilai atau pendidikan menghidupkan nilai. Pendidikan karakter melalui peroses penanaman nilai-nilai kebaikan meliputi komponen pengetahuan, kesadaran atau kemauan melaksanakan nilai-nilai kebaikan tersebut. Karakter atau nilainilai kebaikan itu bukan diajarkan tetapi dicontohkan. Sehingga mahasiswa memiliki kebiasaan (habituation) tentang hal baik dan buruk, yang diperoleh melalui pemahaman (kognitif), kemudian mampu merasakan (afektif) nilai-nilai 
kebaikan itu dan menjadi terbiasa untuk terus menerus melakukannya (psikomotorik).

Pembinaan karakter menjadi tanggung jawab bersama baik itu keluarga, masyarakat, dan negara, maka pihak lembaga pendidikan sangat besar peranannya dalam membina karakter mahasiswa. Oleh karena itu harus ada program khusus atau mata kuliah tersendiri untuk membina karakter tersebut, atau setidaknya pembinaan karakter melalui penanaman nilai-nilai kebaikan terintegrasi pada setiap program kegiatan dan mata kuliah yang ada di perguruan tinggi.

\section{Living Values Education}

Pendidikan nilai (Values education) berkaitan erat dengan kebaikan, yang ada dalam sesuatu baik itu subjek ataupun objek. Mungkin saja sesuatu objek atau subjek itu baik tetapi tidak bernilai bagi seseorang dalam suatu konteks permasalahan tertentu. Misalnya pakaian indah itu baik, tetapi bagi seorang bagi seseorang yang terdampar di suatu pulau dan tidak ada yang menemani, maka pakaian indah itu tidak memberikan makna nilai apa-apa. Oleh karena itu "kebaikan" itu lebih melekat pada objeknya atau pada permasalahannya, sedangkan nilai lebih menunjukkan pada sikap seseorang terhadap sesuatu yang baik. (Hamid Darmadi, 2012 : 4)

Konsep pendidikan nilai merupakan komponen yang menyentuh filosofi tujuan pendidikan yaitu memanusiakan manusia, membangun manusia paripurna atau manusia seutuhnya. (Zaim alMubarak, 2009 : 12) Untuk mewujudkannya berarti menumbuhkan pendidikan nilai (Living Values Education) yang bersendikan nilai-nilai yang tinggi dan esensial kedudukannya dalam kebudayaan. Salah satu konsep filosofi dasar pendidikan nilai menurut Theodore Bramelt adalah pendidikan harus mampu menjadi agen atau perantara yang menanamkan nilai-nilai yang ada dalam jiwa stake holder. Mendidik juga berarti memasukkan anak ke dalam alam nilai-nilai, atau memasukkan dunia nilai-nilai ke dalam jiwa anak. Inilah dasar etika pendidikan nilai. (Zaim alMubarak, 2009 : 15) 
Living Values Education merupakan kegiatan pengajaran nilai-nilai kehidupan melalui aktivitas-aktivitas berdasarkan nilai. Aktivitas-aktivitas dirancang untuk memotivasi murid dan mengajak mereka untuk memikirkan diri sendiri, orang lain, dunia, dan nilai-nilai dalam cara yang saling berkaitan. Kegiatan-kegiatan ini bertujuan untuk merasakan pengalaman di dalam diri sendiri dan untuk membangun sumber daya diri. Kegiatan-kegiatan ini juga bertujuan untuk memperkuat dan memancing potensi, kreativitas, dan bakatbakat tiap murid. Para murid diajak untuk berefleksi, berimajinasi, berdialog, berkomunikasi, berkreasi, membuat tulisan, menyatakan diri lewat seni, dan bermain-main dengan nilai-nilai yang diajarkan. Dalam prosesnya, akan berkembang keterampilan pribadi, sosial, dan emosional, sejalan dengan keterampilan sosial yang damai dan penuh kerja sama dengan orang lain. Nilai-nilai ini telah disusun sedemikian rupa sehingga menyediakan serangkaian keterampilan yang dibangun satu di atas yang lain. Latihanlatihan yang ada termasuk membangun keterampilan menghargai diri sendiri, keterampilan komunikasi social yang positif, keterampilan berpikir kritis, dan menyatakan diri lewat seni dan drama.

\section{Living Values Education Program}

Living Values Education Program bermula dari proyek internasional yang dimulai tahun 1995 oleh Brahma Kumaris dalam rangka merayakan ulang tahun PBB yang ke-50. Saat itu diberi nama Sharing Our Values for a Better World (berbagi Nilai-nilai kita untuk Dunia yang lebih Baik), proyek ini terfokus pada dua belas (Diane Tilman, 2004 : xx-xxi) nilai-nilai universal. Temanya diambil dari pasal dalam pembukaan perjanjian PBB yang berbunyi: "To reaffirm faith in fundamental human rights, in the dignity and worth of the human person..." (untuk menguatkan kepercayaan pada hak-hak asasi manusia, harga diri dan kelayakan seorang manusia...). (Diane Tilman, 2004 : xi-xii)

Tujuan adanya Living Values Education Program adalah :

1. Untuk membantu individu memikirkan dan merefleksikan nilai-nilai yang berbeda dan implikasi praktis bila mengekspresikan nilai tersebut dalam 
hubungannya dengan diri sendiri, orang lain, masyarakat dan seluruh dunia.

2. Untuk memperdalam pemahaman, motivasi dan tanggung jawab saat menentukan pilihan-pilihan pribadi dan social yang positif.

3. Untuk menginspirasi individu memilih nilai-nilai pribadi, social, moral dan spiritual dan menyadari metode-metode praktis dalam mengembangkan dan memperdalam nilai-nilai tersebut.

4. Untuk mendorong para pengajar dan pengasuh memandang pendidikan sebagai sarana memberikan filsafat-filsafat hidup kepada peserta didik, dengan demikian memfasilitasi pertumbuhan, perkembangan dan pilihan-pilihan mereka sehingga mereka bias berintegrasi dengan masyarakat dengan rasa hormat, percaya diri dan tujuan yang jelas. (Diane Tilman, $2004: x i)$.

Ada tiga asumsi dasar Living Values Education Program dilakukan :

1. Nilai-nilai universal mengajarkan penghargaan dan kehormatan tiaptiap manusia. Belajar menikmati nilai-nilai ini menguatkan kesejahteraan individu dan masyarakat pada umumnya.

2. Setiap murid benar-benar memperhatikan nilai-nilai dan mampu menciptakan dan belajar dengan positif bila diberikan kesempatan.

3. Murid-murid berjuang dalam suasana berdasarkan nilai dalam lingkungan yang positif, aman dengan sikap saling menghargai dan kasih sayang di mana para murid dianggap mampu belajar menentukan pilihan-pilihan yang sadar lingkungan.

Living Values An Educatinal Program (LVEP) adalah suatu program pendidikan nilai-nilai. Program ini menyajikan berbagai macam aktivitas pengalaman dan metodologi praktis bagi para pendidik untuk membantu anakanak dan remaja juga dewasa muda untuk mengekslorasi dan mengembangkan nilai-nilai kunci pribadi dan sosial seperti nilai-nilai kedamaian, penghargaan, cinta, tanggungjawab, kebahagiaan, kerjasama, kejujuran, kerendahan hati, toleransi, kesederhanaan dan persatuan. LVEP ini telah diaplikasikan di 1.800 lokasi yang tersebar di 64 negara. Para pengajar 
melaporkan bahwa para peserta didik sangat menanggapi aktivitas-aktivitas nilai yang diberikan dan menjadi gemar mendiskusikan dan mengaplikasikan nilai-nilai kehidupan. Dan yang lebih menarik adalah peserta didik menjadi lebih percaya diri, lebih menghargai orang lain, dan menunjukkan peningkatan keterampilan sosial dan pribadi yang positif dan kooperatif. (Diane Tilman, $2004: x)$

Pada dasarnya setiap individu memiliki nilai-nilai kehidupan. Baik nilainilai agama maupun nilai budaya yang menjadi pandangan hidup (way of life) dan membentuk sikap dalam menghadapi dinamika kehidupan yang sangat kompleks. (Hasbollah Toisuta, 2011: 7). Nilai-nilai kehidupan yang dimiliki itu sejatinya harus ditumbuhkan dan dikembangkan sehingga menjadi suatu karakter. Karena pada saat ini para pendidik dan anak-anak semakin khawatir akan terpengaruh oleh kekerasan, masalah-masalah sosial yang meningkat dan kurangnya rasa saling menghormati di antara sesama dan di dalam lingkungan sekitar. Sebagian besar orang tua dan pendidik sedang mencari jalan untuk membantu anak dan siswa mereka agar dapat memiliki kepercayaan diri dan dapat beradaptasi secara sosial. Sehingga mereka dapat mengerti bagaimana menghadapi persoalan sendiri, tidak terpengaruh negatif dari teman sebaya dan mampu mengarungi masa-masa yang sulit. (Diane Tilman, 2004 : xi). Oleh karena itu untuk menjawab persoalan tersebut peneliti menggunakan teori pembinaan karakter dengan konsep Living Values Education sebagai salah satu alternatif solusi pembinaan karakter bagi mahasiswa, dengan didukung oleh beberapa teori pembinaan karakter, moral dan budi pekerti.

Pembinaan Karakter merupakan proses mengukir atau memahat jiwa sedemikian rupa, sehingga menjadi pribadi yang unik, menarik, dan berbeda atau dapat dibedakan dengan orang lain. Ibarat sebuah huruf dalam alfabet yang tak pernah sama antara yang satu dengan yang lain, demikianlah orangorang yang berkarakter dapat dibedakan satu dengan yang lainnya. (Darma Kesuma dkk, 2012 : 106-107). 
Berdasarkan hal tersebut di atas, peneliti meyakini bahwa proses pembinaan karakter dengan konsep living values education ini bukan memberikan warna kepada anak tentang suatu nilai, melainkan suatu proses interaksi alamiah yang selalu didasarkan kepada nilai. (Darma Kesuma dkk : 2012, 106-107). Maka yang terjadi adalah bukan memaksakan satu nilai kepada anak melainkan mengarahkan dan menguatkan satu nilai kehidupan yang sejatinya dapat menjadi sikap hidup sehari-hari.

\section{Living Values Education sebagai alternatif mata kuliah}

Living Values Education ( $L V E$ ) merupakan aktivitas penanaman nilai atau internalisasi nilai-nilai dalam kehidupan sehari-hari untuk mewujudkan kedamaian, LVE dapat dijadikan sebagai mata kuliah alternatif pembinaan karakter berdasarkan pada :

1. Living Values Education (LVE) itu menjadi dasar atau pondasi penanaman nilai-nilai kehidupan. Seperti yang dilaksanakan di perguruan Tinggi Malaysia dalam waktu 2 semester berturut-turut (semester awal), dengan alasan bahwa LVE itu Islami karena di dalamnya itu ada proses penanaman nilai-nilai ketauhidan, social kemasyarakatan secara kaffah hanya saja yang pertama kali mengembangkan konsep ini orang-orang Barat. Sejalan juga dengan al-Gazali yang mengatakan bahwa untuk ma'rifatullah (mengenal Allah) itu harus punya nilai ikhlas dan jujur

2. Living Values Education (LVE) merupakan program pendidikan nilai melalui berbagai aktivitas pengalaman nilai yang memotivasi seseorang untuk menemukan diri sendiri,

3. Living Values Education (LVE) dapat diintegrasikan dengan mata kuliah yang lain, sehingga para dosen yang mengajar, mengarahkan mahasiswa pada pengamalan nilai-nilai baik dalam kehidupan.

Living Values Education ( $L V E)$ dapat diintegrasikan dengan mata kuliah apapun yang ada di lembaga pendidikan Tinggi dengan syarat semua pihak mulai dari unsur pimpinan, staf pengajar secara keseluruhan, staf administrasi 
dan para mahasiswa senior bahkan alumni, turut serta melakukan pembinaan dalam arti pembentukan kebiasaan yang terus menerus dilakukan, terutama pemberian contoh atau teladan. Jadi model atau strategi pembelajaran yang dilakukan adalah menekankan pada pembelajaran proses, dan pengamatan yang terus menerus sehingga system penilaiannya pun penilaian proses. Rektor Universitas Paramadina mengatakan bahwa bahwa proses itu lebih penting dibandingkan hasil. Hasil yang baik belum tentu prosesnya baik tetapi jika prosesnya baik maka hasilpun akan maksimal. Oleh karena itu harus melalui pembiasaan yang positif, karena itu lebih penting.

\section{Penerapan Living Values Education}

Penciptaan suasana berdasarkan nilai akan sangat membantu memfasilitasi keberhasilan penanaman nilai-nilai sehingga tercipta kesadaran nilai. Refleksi nilai melalui pengungkapan ide-ide tentang sesuatu berdasarkan nilai dan membayangkan lingkungan kelas yang optimal penuh dengan nilai. Hanya mendengar tentang nilai-nilai tidaklah memadai untuk mahasiswa maka agar mereka dapat benar-benar mempelajarinya, peneliti berusaha mengajak mahasiswa untuk mengalami nilai dalam berbagai tingkatan dan menjadikan nilai-nilai tersebut bagian dari mereka. Dengan hanya merasakan, mengalami, dan memikirkan nilai-nilai tidak juga cukup, maka dibutuhkan untuk melatih keterampilan-keterampilan sosial agar dapat menggunakan nilai tersebut di kegiatan sehari-hari. Mahasiswa harus dapat melihat efek-efek perilaku dan pilihan-pilihan mereka dan mampu mengembangkan keterampilan pengambilan keputusan yang sadar lingkungan. Dengan demikian diharapkan mereka mampu membawa serta nilai-nilai tersebut tidak hanya ke dalam diri pribadi melainkan juga ke dalam masyarakat yang lebih luas, sehingga sangat penting bagi mereka untuk menjelajahi topik-topik keadilan sosial dan melihat tauladan dari dosen yang memberikan contoh nilai-nilai tersebut.

Proses penanaman nilai-nilai tersebut melalui berbagai metode atau strategi pembelajaran diantaranya: 


\section{Berimajinasi}

Peneliti meminta mahasiswa membayangkan dunia yang penuh damai dan meminta mereka untuk berbagi pengalaman dan membuat gambar tentang damai. Latihan imajinasi ini memancing kreatifitas mahasiswa yang baik atau memancing ketertarikan mahasiswa yang "cuek" atau "bermotivasi rendah". Visualisasi membuat nilai-nilai menjadi lebih relevan dengan mahasiswa karena mereka mencari tempat dalam diri sendiri sehingga mengalami sendiri kualitas nilai tersebut dan mampu menghasilkan ide.

\section{Latihan Relaksasi/Fokus}

Keheningan seringkali tidak disukai dan tidak dapat dinikmati, karena hening dianggap sebagai sesuatu yang menekan energi dan menghilangkan kegembiraan, namun sebenarnya latihan relaksasi atau fokus ini membantu mahasiswa mampu menikmati "perasaan" dari nilai-nilai tersebut. Tujuannya membantu mahasiswa menjadi lebih tenang, lebih puas diri dan lebih baik dalam berkonsentrasi saat belajar.

\section{Ekspresi Seni}

Peneliti memotivasi mahasiswa untuk berefleksi tentang nilai dan mengalami nilai tersebut dengan artistik dan kreatif melalui kesenian. Misalnya meminta mahasiswa membuat gambar tentang kedamaian, memahat cinta, melukis penghargaan, membuat tarian persatuan dan membuat lagu keTuhanan. Dari berbagai aktivitas seni itu diharapkan mahasiswa mampu menangkap nilai dan memulai mengembangkannya dalam keseharian.

\section{Aktivitas Pengembangan Diri}

Mahasiswa diminta untuk mengeksplor nilai yang terkait dengan diri mereka sendiri atau membangun keterampilan yang berkaitan dengan nilai. Misalnya mahasiswa melihat sifat-sifat baik mereka sendiri dalam nilai Penghargaan, sehingga mereka mampu memilih kata-kata yang membawa kebahagiaan untuk diri sendiri dan orang lain. Atau misalnya dalam suatu aktivitas nilai kejujuran, mahasiswa diharapkan mampu memeriksa perasaan mereka ketika berlaku jujur. Dari aktivitas ini banyak sekali respon yang 
diberikan dan secara positif tentunya peneliti meng iya kan respon-respon tersebut.

\section{Keterampilan sosial}

Peneliti meminta mahasiswa untuk mengungkapkan beberapa keterampilan sosial, misalnya nilai cinta, mahasiswa mengeksplorasi caracara menggunakan kata-kata yang baik atau memilih setangkai bunga untuk mengatakan cinta, begitu juga dengan nilai penghargaan, mahasiswa mengeksplorasi cara-cara halus dan kurang kurang halus untuk menunjukkan penghargaan dan penghinaan. Aktivitas ini menyenangkan sehingga menimbulkan komentar-komentar yang reflektif dari mahasiswa, dengan demikian mengajak mahasiswa untuk lebih melakukan nilai-nilai sosial tersebut secara lebih baik.

\section{Kesadaran kognitif tentang keadilan sosial}

Melalui aktivitas latihan nilai melalui forum diskusi, mahasiswa termotivasi untuk melihat kembali akibat dari tindakan mereka terhadap orang lain dan bagaimana bisa membuat perbedaan. Misalnya pada nilai persatuan, mahasiswa diminta untuk mendeskrifsikan persatuan dan bukan persatuan berdasarkan sejarah atau ilmu sosial. Kemudian mereka diminta untuk melihat apa pengaruh dari persatuan dan bukan persatuan (cerai berai), apa perasaan mereka melihat keadaan itu. Dari aktivitas ini terlihat mahasiswa diajak untuk memiliki lebih baik nilai tanggung jawab, toleransi dan penghargaan terhadap lingkungan sosial, sehingga membantu mewujudkan lingkungan yang penuh damai dan cinta.

Berdasarkan hasil wawancara dan diskusi peneliti dengan mahasiswa tentang beberapa nilai dengan metode seperti di atas, peneliti meyakini bahwa penanaman nilai melalui program Living Values Education, baik terintegrasi dengan mata kuliah lainnya atau tersendiri seperti mata kuliah character building sangat membantu mahasiswa untuk mengenali diri sendiri dan harus berbuat apa untuk orang lain yang ada di lingkungan sosial hidupnya. 


\section{KESIMPULAN}

Berdasarkan hasil penelitian diatas, penulis menyimpulkan bahwa Living Values Education merupakan aktivitas penanaman nilai atau internalisasi nilai-nilai dalam kehidupan sehari-hari untuk mewujudkan kedamaian, penghargaan, cinta, persatuan dan ketuhanan (religious). Semua nilai itu ditumbuhkembangkan dalam kehidupan sehari-hari. Baik itu sebagai mata kuliah pembinaan karakter tersendiri maupun pendidikan menghidupkan nilai tersebut dengan mengintegrasi dengan semua mata kuliah yang ada terlebih jika semua staf pengajar (dosen) menjadi tauladan bagi mahasiswa.

Penelitian ini menambah keyakinan peneliti bahwa pendidikan menghidupkan nilai sangat membantu peneliti dalam pembinaan karakter mahasiswa, baik itu dalam pendidikan dan pengajaran, pembimbingan akademik lainnya maupun pengabdian masyarakat. Mahasiswa menyadari bahwa nilai itu harus ditumbuhkembangkan dalam dirinya sebagai self control untuk menjalani setiap pembelajaran.

Berdasarkan hal itu, peneliti menyarankan agar Living Values Education ini dijadikan program khusus untuk pembinaan karakter mahasiswa pada awal semester agar membantu para dosen dalam membimbing baik itu bimbingan akademik maupun bimbingan lainnya.

\section{DAFTAR PUSTAKA}

[1] Diane Tillman dan Diana Hsu. Living Values Education for Children. Jakarta: Grasindo, 2004.

[2] Diane Tilman. Living Values Activities for Young Adults. Jakarta: Grasindo, 2004.

[3] Diane Tilman. Living Values Parent Groups. Jakarta: Grasindo, 2004.

[4] Diane Tillman dan Pillar Quera Colomina. LVEP Educator Training Guide (Jakarta: Grasindo, 2004. 
[5] Darma Kesuma dkk. Pendidikan Karakter: Kajian Teori dan Praktik di Sekolah. Bandung: PT. Remaja RosdaKarya, 2012.

[6] Muhammad Rustar. "Pendidikan Karakter menurut Ki Hajar Dewantara". Tesis UIN Syarif Hidayatillah, 2010.

[7] Nufus, Ahmad Hayati. Pendidikan Dan Politikus: Analisis Pemikiran M. Natsir Tentang Pendidikan Islam Di Indonesia. al-Iltizam: Jurnal Pendidikan Agama Islam 3.12018.

[8] Seto Mulyadi, Homeschooling Keluarga Kak Seto: Mudah, Murah, Meriah dan Direstui Pemerintah. Bandung: Kaifa, 2007.

[9] Sugiyono, Memahami penelitian Kualitatif. Bandung : Alfabeta, 2012.

[10] S. Margono. Metodologi Penelitian Pendidikan. Jakarta: Rineka Cipta, 2004.

[11] Sumadi Suryabrata. Metode Penelitian. Jakarta : Raja Grafindo Persada, 2012.

[12] Zeim alMubarak. Membumikan Pendidikan Nilai. Bandung: Alfabeta, 2009. 